Renata Przybylska ๑

Uniwersytet Jagielloński, Kraków

renata.przybylska@uj.edu.pl

\title{
KOLOKACJE A ANALIZA SEMANTYCZNA WYRAZU
}

Słowa klucze: związki syntagmatyczne, kolokacje, frazeologia, językoznawstwo korpusowe, semantyka leksykalna, leksykografia

Keywords: syntagmatic expressions, collocations, phraseology, corpus linguistics, lexical semantics, lexicography

Każde bowiem słowo ma określone wymagania wobec elementów, które sąsiadują z nim w kontekście.

Danuta Buttler

Pojęcie kolokacji wprowadził do językoznawstwa John Rupert Firth, twórca kontekstowej teorii znaczenia, jednak nie podał jego precyzyjnej definicji, posługując się tylko przykładem ilustrującym to zjawisko, por.: „jednym ze znaczeń wyrazu noc jest oczywiście jego połączenie z wyrazem ciemna" ${ }^{\prime}$. O kolokacjach i kolokacyjnych ograniczeniach pisze John Lyons (1984: 253-259) w rozdziale Semantyki poświęconym syntagmatycznym relacjom leksykalnym oraz w rozdziale o kontekstowej teorii znaczenia. Przypomina on też poglądy Waltera Porziga, który związki między wyrazami typu: lizać i język, szczekać i pies, blond i włosy nazwał „przyrodzonymi relacjami znaczeniowymi" (niem. wesenhafte Bedeutungsbeziehung), zwracając uwagę na fakt, że objaśnienie znaczenia jednego z tych wyrazów, np. słowa blond, nie może się obyć bez przywołania słowa włosy, podobnie aby objaśnić czasownik

1 Cyt. za: Lyons 1984: 225, który powołuje się na pracę Johna R. Firtha Papers in Linguistics, 1957. 
lizać, trzeba przywołać słowo język, a szczekać - słowo pies itp. Tłumacz Lyonsa, Adam Weinsberg, spolszczył termin kolokacja jako połaczenie, używał też pochodnego przymiotnika połaczeniowy w znaczeniu 'kolokacyjny'. Termin kolokacja jest rozumiany na użytek niniejszego tekstu dość szeroko, jako nazwa odnosząca się do różnorakich związków wyrazowych (syntagmatycznych), w które wchodzi w tekstach dany wyraz hasłowy. Zwykle w szerokim, luźnym rozumieniu kolokacja definiowana jest jako „związek frazeologiczny będący często używanym zestawieniem słów (znacznie częściej niż inne zestawienia o tym samym znaczeniu), w którym w odróżnieniu od idiomu - sens całości wynika ze znaczeń poszczególnych wyrazów, np.: obrać jabłko, odczuwać tęsknotę, mocna kawa, silny wiatr, na Wegrzech, we Francji”" W W węższym rozumieniu kolokacja to nie każde możliwe połączenie wyrazowe, lecz tylko takie, w którym łączenie się danego wyrazu z innym jest wynikiem pewnych restrykcji semantycznych lub uzualnych, np. mocna kawa w tym węższym rozumieniu jest kolokacją, jako że nie mówimy po polsku * ${ }^{\star} i l n a$ kawa, podczas gdy połączenia: goraca kawa, słodka kawa itp. nie stanowiłyby przykładów tak wąsko rozumianych kolokacji.

Trzeba odróżnić pojęcie kolokacji od pojęcia kookurencji (ang. coocurence lub co-ocurence), czyli prostego współwystępowania obok siebie w tekście danych wyrazów, przy czym owo współwystępowanie nie musi wcale być wynikiem istniejącego między wyrazami związku składniowego (syntagmatycznego), a tym bardziej znaczeniowego. Kookurencja może być wskaźnikiem idiomatyczności danej syntagmy, np. hulaj dusza lub wskaźnikiem semantycznego pokrewieństwa. W literaturze przedmiotu pojawił się też termin leksykalna solidarność, wprowadzony przez Eugenio Coșeriu (1978). Nieco zbliżonym pojęciem jest ponadto konkordancja, termin oznaczający „zbiór przykładów użycia danej formy wyrazowej, z których każdy jest przedstawiony w swoim własnym środowisku tekstowym" (Lewandowska-Tomaszczyk 2005: 296).

Jednym z pierwszych użyć terminu kolokacja w pracy skierowanej do szerszej publiczności jest pojawienie się go w tytule jednej z części Wielkiego słownika frazeologicznego Renardy Lebdy (2009): Tematyczny słownik wybranych kolokacji, wyrażeń $i$ zwrotów w języku polskim i angielskim.

Pojęcie kolokacji wiąże się z pojęciem stopnia siły/mocy przyciągania się wyrazów nawzajem, czyli ich łączliwości. Klasyk polskiej frazeologii Stanisław Skorupka (1967) dzielił związki wyrazowe na: 1. luźne, 2. łączliwe, 3. stałe. Stałe związki frazeologiczne oczywiście znajdą się poza badanym zbiorem kolokacji, bowiem występujący w nich badany wyraz w istocie jest tylko graficznym segmentem - członem frazeologizmu, który to frazeologizm stanowi odrębną, choć graficznie wielosegmentową, jednostkę leksykalną, np. biały kruk, brzydkie kaczątko, żyła złota, złoty strzał, żelazna kurtyna. Natomiast zarówno związki luźne, jak i związki łącz-

2 Cyt. za: http://sjp.pl/kolokacja. 
liwe znajdują się w naszym polu obserwacji, przy czym warto zaznaczyć, że w większości wypadków zupełnie odrzucamy te związki, które są skrajnym przykładem zupełnie luźnej, niczym nieograniczonej łączliwości. Oczywiście łączliwość wyrazów jest kwestią stopnia, ewentualnej przewidywalności takiej czy innej konstrukcji.

Łączliwość wyrazów stała się też przedmiotem rozważań normatywnych Danuty Buttler (1982: 182-210) w pracy zbiorowej Kultura języka polskiego. Badaczka rozróżnia łączliwość kategorialną (systemową), dającą się ująć w pewne reguły, polegającą na respektowaniu zasad tzw. zgody semantycznej między łączonymi wyrazami wynikającej wprost z ich znaczenia, oraz łączliwość - jak ją nazywa - normatywną, zwyczajową, niedającą się ująć w reguły, wynikającą z uzusu. Jak pisze:

Łączliwość normatywną można byłoby też nazwać indywidualną, ponieważ przysługuje ona wyrazowi jako jednostce, a nie jako reprezentantowi jakiejś klasy, i jest ona dla niego równie charakterystyczna, jak określony sposób odmiany czy taka, a nie inna postać fonetyczna i słowotwórcza (ibid.: 184).

Buttler dostrzega zatem to, że opis wyrazu z punktu widzenia opisu języka może i powinien obejmować też pełny opis jego łączliwości. Jest to zatem zadanie dla leksykografii.

W słownikach jednojęzycznych języka polskiego tzw. kolokacje czy inaczej połączenia wyrazowe nie znajdowały dotychczas szczególnie dokładnej dokumentacji. Historię odnotowywania w słownikach jednojęzycznych polszczyzny interesujących nas tu połączeń wyrazowych przedstawia w swoim artykule Tadeusz Piotrowski (2008). W polskich słownikach ogólnych zazwyczaj w artykule hasłowym podawano kilka dość arbitralnie, jak się wydaje, wybranych związków wyrazowych, będących $\mathrm{w}$ istocie przypadkową ilustracją sposobu najczęstszego użycia wyrazu. Tymczasem kolokacje właśnie są tą częścią informacji leksykograficznej, która pokazuje, jak $\mathrm{w}$ tekstach dany wyraz jest faktycznie używany, jak różne użycia/konteksty cieniują jego potencjalne szersze znaczenie, uwypuklając jakiś składnik znaczenia, a przesuwając na dalszy plan inny. Jednym z pierwszych słowników połączeń wyrazowych, ale bardzo ograniczonym co do liczby haseł, jest popularnonaukowe dzieło Stownik dobrego stylu, czyli wyrazy, które się lubią Mirosława Bańki (2006). Słownik ten dokumentuje - według tego, co pisze autor we wstępie - 70 ooo połączeń wyrazowych dla 5000 haseł. Drugim jest słownik z 2007 r. Ewy Geller i Andrzeja Dąbrówki pt. Słownik stylistyczny języka polskiego, który zawiera 100 ooo kolokacji dla ponad 1600 wybranych słów hasłowych. T. Piotrowski jego układ i zawartość poddał szczegółowej, momentami krytycznej ocenie.

W opracowaniu redakcyjnym hasła słownikowego etap gromadzenia kolokacji, ich przeglądu, porządkowania i analizy poprzedzać powinien refleksję zarówno nad liczbą wyłonionych znaczeń (podhaseł) danego wyrazu, jak i jego definicją semantyczną. Z tego względu warto bliżej przyjrzeć się praktycznym badaniom połączeń wyrazowych, służącym ulepszeniu opisu leksykograficznego słownictwa. 
Pierwszy etap - gromadzenia kolokacji będących podstawą analizy semantycznej wyrazu - wbrew pozorom nie jest zadaniem czysto mechanicznym, lecz wymaga świadomego zastosowania określonych narzędzi badawczych tak, aby już na tym etapie ustrzec się błędów. Szczęśliwie istnieją obecnie korpusy językowe, z których można pozyskiwać kolokacje, w podobnym celu można bezpośrednio wykorzystać zasoby Internetu. Chodzi o to, aby wyłonić połączenia wyrazowe, które są: 1. najczęstsze, 2. poznawczo istotne dla semantyki badanego wyrazu hasłowego.

Ustalenie, które kolokacje są najczęstsze, jest wiarygodne tylko wtedy, gdy źródłem kolokacji jest korpus zrównoważony. Korpusy jednostronne stylistycznie, zdominowane przez jakiś styl funkcjonalny bądź ograniczone tematycznie, specjalistyczne mogą dać wyniki dla ogólnego języka polskiego nieadekwatne. Z drugiej strony - to na marginesie - można sobie wyobrazić doskonałą leksykalną charakterystykę stylów funkcjonalnych lub tekstów o określonej tematyce wynikającą właśnie z przedstawienia kolokacji charakterystycznych dla danych typów tekstów (por. np. wyłonienie kolokacji typowych dla języka prawa czy dla stylu urzędowego).

Kwestia częstości danych połączeń na tle innych sprowadza się do częstości względnej, przy czym problemem są sytuacje, kiedy dana kolokacja wypełnia np. więcej niż 50\% próby, w ten sposób rugując z pola obserwacji część kolokacji także częstych, ale nie $\mathrm{w}$ tak przytłaczającej mierze. Kłopotliwe są też sytuacje, kiedy w zbiorze kolokacji odnajdujemy składniki idiomów - stałych związków frazeologicznych, wówczas należy te idiomy wyłączyć z badanego zbioru. Na tym etapie badacz staje przed koniecznością niełatwego rozgraniczenia między kolokacjami a frazeologizmami. Jak wiadomo, określona decyzja w tym względzie podjęta przy analizie hasła $\mathrm{X}$ rzutuje na sposób rozwiązania opisu w haśle Y. Przykładowo jeśli z kontekstów: odesłaćlodsyłać kogoś na zielona trawkę; posłaćlposyłać kogoś na zielona trawkę; pójśćliść na zielona trawkę; wyrzucać kogoś na zielona trawkę; wysłaćl wysyłać kogoś na zielona trawkę; wyladowaćllądować na zielonej trawce; znaleźć się na zielonej trawce wyłonimy jednostkę leksykalną frazeologizm na zielona trawkę I na zielonej trawce, to tym samym uznamy powyższe połączenia tej frazy z czasownikami za kolokacje i odrzucimy rozwiązanie takie, aby tworzyć frazeologizmy zwroty czasownikowe - w rodzaju: ktoś odesłał kogoś na zielona trawkę, ktoś posłał kogoś na zieloną trawkę itd.

Przeszukiwanie korpusów wymaga oczywiście zastosowania odpowiedniej składni zapytań. Dla każdej części mowy składnia zapytań jest specyficzna i wynika z możliwych zależności składniowych, w jakie wchodzi dany wyraz, tworząc określone kolokacje. Dla rzeczownika zaproponowałam swego czasu pewien składniowy szkielet potencjalnie możliwych połączeń tej części mowy z innymi wyrazami / częściami mowy (Przybylska 2007), tu zwrócę tylko uwagę na fakt, że dla rozpoznania semantyki wyrazu okazują się istotne nie tylko użycia rzeczownika w pozycji nadrzędnika lub podrzędnika, lecz także jako składnika szeregu współrzędnego zarówno spójnikowego, jak i bezspójnikowego. 
W pozyskiwaniu (ekstrakcji) kolokacji przydatny może być tzw. kolokator, moduł ich automatycznej ekstrakcji zastosowany w wyszukiwarce PELCRA udostępnianej użytkownikom Narodowego Korpusu Języka Polskiego. Kolokator umożliwia zdefiniowanie kryteriów kolokatu dla danego ośrodka kolokacji, np. dla rzeczownika, i w ten sposób stworzenie jego tzw. profilu kolokacyjnego. W tabeli wyników uzyskuje się dane na temat ogólnej liczby wystąpień ośrodka kolokacji w korpusie, liczby przeanalizowanych kontekstów oraz liczby potencjalnych kolokacji. Najważniejszą informacją jest podawana w ostatniej kolumnie tabeli wyników wartość chi kwadrat $\left(\mathrm{X}^{2}\right)$, która „wyraża prawdopodobieństwo tego, że częstotliwość współwystępowania ośrodka kolokacji z danym wyrazem w korpusie nie jest przypadkowa" (Narodowy Korpus Języka Polskiego 2012: 269), lecz statystycznie istotna. Wartość $\mathrm{X}^{2}$ decyduje o sortowaniu wyników - kolokacje są układane w porządku malejącym: od tych, które mają najwyższą wartość $\mathrm{X}^{2}$, czyli są statystycznie istotne, do tych, które mają tę wartość najniższą. Na przykład dla słowa nisza kolokator podaje jako statystycznie istotne połączenia z wyrazami: rynkowa, ekologiczna, poszukiwać, poszukiwanie, szukać, nowa.

Narzędzie, jakim jest kolokator PELCRA, wymaga jednak doskonalenia. W chwili obecnej lepsza $\mathrm{w}$ celu pozyskiwania kolokacji wydaje się oferowana przez NKJP wyszukiwarka Poliqarp. Typowe kolokacje danego wyrazu można w niej wydobyć przez zwykłe sortowanie konkordancji po lewej lub prawej stronie. Stosując właściwą składnię zapytań i przeglądając współwystępujące z danym ośrodkiem kolokacji kolokaty, można uzyskać bardzo bogate i pouczające wyniki. I tak dzięki wyszukiwarce Poliqarp można ustalić następujące kolokacje dla niszy: głęboka, mała; kamienna; półkolista, wykuta; nowa, swoja, własna, niezagospodarowana nisza; nisza grobowa, grzebalna, okienna, sypialna, ścienna, urnowa; niwalna, osuwiskowa, skalna; szukać, poszukiwać niszy; znaleźć, zapetnić niszę.

W rezultacie analizy kolokacji i szerszych kontekstów wyłania się frazeologizm: nisza ekologiczna i cztery znaczenia: 1. 'wnęka w murze, półkolista lub prostokątna, służąca najczęściej jako miejsce do ustawienia w niej rzeźby’ z kolokacjami: grobowa, specjalna, pusta nisza; 2. 'wgłębienie w pionowej skale, w lodzie, w którym może zmieścić się człowiek' z kolokacjami: głęboka, niewielka, niwalna, osuwiskowa, skalna nisza; nisza $w$ skale, w ścianie skalnej; 3. 'część pomieszczenia cofnięta w głąb w stosunku do jednej ze ścian' z kolokacjami: boczna, pótkolista, sypialna nisza; nisza okienna; 4. 'pozostawiony w jakiejś dziedzinie działalności człowieka niezagospodarowany obszar, w którym może się rozwijać coś uzupełniającego, drugoplanowego' z kolokacjami: niezagospodarowana nisza; nisza rynkowa, gospodarcza; kulturowa; szukać, poszukiwać niszy; znaleźć (swoja) niszę, zapelnić niszę (zob. WSJP PAN). Badanie kolokacji pozwala wyłaniać nowe znaczenia danego wyrazu, tak się stało w odniesieniu do powyżej przytoczonego znaczenia $\mathrm{nr}$ 4, dzięki temu że zaobserwowano połączenia rzeczownika nisza z nowymi kolokatami o znaczeniu abstrakcyjnym. 
Warto zauważyć, że np. w USJP odnotowano tylko konkretne znaczenie dla $n i-$ szy, nie pojawiło się natomiast nowsze znaczenie abstrakcyjne typu nisza rynkowa.

Obecne zasoby korpusowe są, jak się wydaje, wystarczające dla pozyskiwania kolokacji słów bardzo częstych i względnie częstych. Niestety dla wyrazów rzadszych, a zwłaszcza dla wszelkich semantycznych i leksykalnych innowacji, korpus ten okazuje się za mały, np. hasło niszowy ma skąpe poświadczenia, por. kolokacje: niszowy produkt, temat, teatr, film, zespół, biznes i ilustracje następującymi cytatami:

Tu właśnie pojawia się szansa na produkt niszowy, czyli buty sportowe dla niepełnosprawnych - niewielu odbiorców, ale za to zdecydowanych na zakup danego towaru. - Od trzech tygodni towarzyszy mi uczucie zaskoczenia i zdumienia odwagą jury. Moja książka to przecież produkt skrajnie niszowy - dodał w podziękowaniu wyraźnie wzruszony Bieńkowski.

Wynika z nich, że ten przymiotnik związany jest z rzeczownikiem nisza tylko $\mathrm{w}$ jego abstrakcyjnym znaczeniu. Czy można sądzić, że w języku funkcjonuje też niszowy związany ze znaczeniem niszy 1 , dotyczącym wnęki? Czy brak takich użyć to wynik niepełności korpusu, przypadkowa „dziura” w jego zasobach czy świadectwo całkowitej nieobecności takiej jednostki leksykalnej w systemie języka polskiego?

W USJP w ogóle brak hasła niszowy.

Drugi etap analizy to oddzielenie kolokacji częstych, ale poznawczo nieistotnych, od tych częstych, które uznajemy za istotne. Na przykład czasownik widzieć w pierwszym, podstawowym znaczeniu 'odbierać bodźce wzrokowe i zauważać kogoś lub coś' (zob. WSJP PAN) tworzy kolokacje z rzeczownikiem (grupą nominalną) w bierniku, jednak nie jest w żaden sposób poznawczo istotne wypełnienie pozycji przybiernikowej takim czy innym wyrazem/wyrazami. Krótko mówiąc, widzieć można cokolwiek, wszystko, i nie wpływa to na semantykę czasownika w tym pierwszym znaczeniu. Jednak już w znaczeniu widzieć 'zapoznawać się z czymś, patrząc na to' typu widzieć film, sztukę, przedstawienie, wystawę; widzieć (coś) w kinie, w telewizji itp. (zob. WSJP PAN) sposób wypełnienia pozycji biernikowej jest bardzo istotny, gdyż kolokaty w pozycji biernika dające się scharakteryzować jako określona, dość jednorodna klasa leksykalno-semantyczna, przesądzają o tym, że wyłania się inne znaczenie tego czasownika i wprowadzana jest odmienna rama semantyczna.

Największe znaczenie dla właściwego rozpoznania i opisu semantyki danego słowa mają kolokacje w przypadku jednostek polisemicznych. Precyzyjne znaczenie danego wyrazu w istocie ujawnia się dopiero w kontekście, właśnie w otoczeniu jego kolokatów. Kolokacje oddają zarazem najbardziej typowy, standardowy sposób użycia danego wyrazu, dokładniej zaś - użycia go w określonym znaczeniu. To one są w stanie zilustrować aktualny uzus, pokazując, na ile trwanie wyrazu w słowniku pociąga za sobą trwanie pewnych konstrukcji i związków wyrazowych, a na ile właśnie te związki wyrazowe podlegają semantycznym i składniowym innowacjom, choć wyraz sam zachowuje swoje zasadnicze znaczenie. 
Zbiór kolokacji ilustrujących użycie danego wyrazu w doskonały sposób odsłania i przywołuje całą ramę semantyczną (w rozumieniu Charlesa Fillmore’a) bądź cały skrypt semantyczny związany $\mathrm{z}$ danym wyrazem jako elementem słownika (por. dżinsy). Szczególnie ważne w zarysowanej ramie semantycznej wyrazu wydają się te elementy, które są kulturowo specyficzne (por. badylarz), a których opis nie mieści się np. ani w definicji, ani w cytatach.

Badanie kolokacji przesądza też o wykrywaniu nowych znaczeń wyrazu, por. np. kwota, barbarzyńca, w tym zwłaszcza tych mających motywację metaforyczną.

Trzeci etap to przypisanie zbiorów kolokacji (pól kolokacyjnych) odpowiednio wyłonionym znaczeniom danego wyrazu. Na tym etapie udaje się też wyłonić dzięki temu znaczenie centralne (jądrowe, pierwotne, konkretne, ang. core meaning) w opozycji do różnorakich znaczeń wtórnych, w których wyraz podstawa podlega zwykle różnym kolokacyjnym restrykcjom, większym niż w znaczeniu centralnym.

W przyswajaniu danego języka zwłaszcza przez cudzoziemców, ale też w rozwijaniu kompetencji językowych jego natywnych użytkowników znajomość kolokacji odgrywa bardzo dużą rolę. Językoznawcy kognitywni zwrócili uwagę na pojawiającą się w opisach języka ich zdaniem fałszywą alternatywę̧: rzekomo albo mamy $\mathrm{w}$ języku do czynienia z wyliczeniem jednostek zdolnych do tworzenia konstrukcji, albo mamy do czynienia z konstrukcjami - produktami operacji na tych jednostkach. Tymczasem obecnie uważa się, że opanowywanie i rozwijanie języka odbywa się równolegle, z wykorzystaniem obu dróg: uczenia się jednostek języka i przyswajania całościowego konstrukcji, które dopiero potem ewentualnie podlegają dekompozycji. Takimi całostkami przyswajanymi z uzusu są właśnie najczęstsze w danym języku kolokacje. I to one mogą być opanowywane najpierw, przed wydzieleniem z nich jednostek leksykalnych. Ostatecznie jednak kolokacje dostarczają przede wszystkim wskazówek, jak użytkownik może skutecznie przejść z poziomu leksyki do konstruowania swej wypowiedzi. Kolokacje podpowiadają mu możliwe w danym języku wzorce łączliwości.

Język polski nie dysponuje naukowym słownikiem kolokacji. Gdyby taki miał powstać, to - przy wykorzystaniu zasobów korpusowych i Internetu - warto by poprzeć wyłonione kolokacje danymi co do ich frekwencji. Ponadto należałoby odpowiednio odznaczyć te kolokacje, które są w kontekście danego wyrazu podstawy specyficzne, innymi słowy np. fakt, że deszcz może być rzęsisty, wielki, ale nie może być * duży, ogromny (deszcz). Być może byłoby wskazane ostrzec użytkownika przed nieopatrzną wymianą standardowych kolokatów na ich rzekome synonimy, które jednak użyte przy danym wyrazie dają w rezultacie kolokację niezgodną z normą i uzusem danego języka, odczuwaną jako co najmniej „dziwna”.

3 Fałszywa alternatywa reguły/listy to termin wymyślony przez Ronalda Langackera, por. Evans 2009: 30-31. 
Nawet jeśli dany wyraz hasłowy jest stylistycznie i funkcjonalnie nienacechowany, neutralny, to może się okazać, że tworzone przezeń kolokacje należą do różnych stylów funkcjonalnych. I o tym fakcie w słowniku kolokacji należałoby także informować, np. stosując system odpowiednich kwalifikatorów.

Jeśli jakaś grupa semantyczno-leksykalna wyrazów charakteryzuje się podobnymi kolokacjami, to warto by dla takiej grupy stworzyć ogólniejsze opisy wymagań i możliwości co do przyłączania takich, a nie innych kolokatów; chodzi np. o nazwy dni tygodnia, miesięcy, kolorów itp. W ten sposób system leksykalny mógłby być charakteryzowany jako struktura złożona z podzbiorów słów o podobnych profilach kolokacyjnych, przy czym owe podobne profile świadczyłyby nie o synonimii, lecz o przynależności do jednej i tej samej podobnie semantycznie ustrukturyzowanej grupy leksykalno-semantycznej. Przykładem takiego podzbioru leksykalnego są nazwy jednostek i odcinków czasu, a także np. nazwy pór roku.

Wydaje się, że badanie kolokacji mogłoby się też okazać ważnym wskaźnikiem stylometrycznym. Odchylenie od standardu mogłoby pokazywać osobliwe, wręcz identyfikujące, cechy stylu i języka danego autora. Zatem ten wskaźnik mógłby też służyć do badania autorstwa tekstów, rozstrzygania o ich prawdziwości lub fałszerstwie itp. Jeśli chodzi o badanie języka artystycznego, to właśnie profile kolokacyjne słów, w tym zwłaszcza tzw. słów kluczy, mogłyby stanowić wartościowy poznawczo składnik charakterystyki języka osobniczego danego twórcy. Taką próbą zastosowania opisu kolokacji do analizy idiolektu pisarza jest studium poświęcone profilowaniu znaczenia leksemu noc w twórczości Konstantego Ildefonsa Gałczyńskiego (Przybylska 2005).

\section{Literatura}

ВАŃко M., 2006, Stownik dobrego stylu, czyli wyrazy, które się lubia, Warszawa.

BUtTLER D., 1982, Zagadnienia normatywne zwiazane z syntagmatycznym doborem elementów leksykalnych, [w:] D. Buttler, H. Kurkowska, H. Satkiewicz, Kultura języka polskiego. Zagadnienia poprawności leksykalnej (słownictwo rodzime), Warszawa, s. 182-210.

Coșeriu E., 1978, Lexikalische Solidaritäten, [w:] H. Geckeler (red.), Strukturelle Bedeutungslehre, Darmstadt, s. 239-253.

Evans V., 2009, Leksykon językoznawstwa kognitywnego, przeł. M. Buchta, Kraków.

FirTH J.R., 1951, Modes of meaning, [w:] J.R. Firth, Papers in linguistics 1934-1951, London New York, s. 190-215.

Geller E., DĄBRówKa A., 2007, Stownik stylistyczny języka polskiego, Warszawa.

LEBDA R., 2009, Wielki stownik frazeologiczny, red. A. Latusek, Kraków.

Lewandowsкa-Tomaszczyк B. (red.), 2005, Podstawy językoznawstwa korpusowego, Łódź. Lyons J., 1984, Semantyka, przeł. A. Weinsberg, Warszawa.

Narodowy Korpus Języka Polskiego, 2012, praca zbiorowa, red. A. Przepiórkowski, M. Bańko, R.L. Górski, B. Lewandowska-Tomaszczyk, Warszawa. 
NKJP: Narodowy Korpus Języka Polskiego, [on-line:] nkjp.pl.

Pęzik P., 2012, Wyszukiwarka PELCRA dla danych NKJP, [w:] A. Przepiórkowski, M. Bańko, R.L. Górski, B. Lewandowska-Tomaszczyk (red.), Narodowy Korpus Języka Polskiego, praca zbiorowa, Warszawa, s. 253-273.

Piotrowski T., 2008, Collocations in Polish dictionaries: history, „Lexicographica. International Annual for Lexicography” 24, s. 159-166.

Przybylska R., 2005, „Noc” - szkic do słownika poetyckiego Gałczyńskiego, [w:] A. Kulawik, J.S. Ossowski (red.), Dzieło i życie Konstantego Ildefonsa Gałczyńskiego, t. I, Kraków, s. $175-187$.

PrZybylska R., 2007, Z problemów słownikowego opisu łączliwości rzeczownika, [w:] P. Żmigrodzki, R. Przybylska (red.), Nowe studia leksykograficzne I, Kraków, s. 69-78.

PrZYbylska R., 2018, Ilustracja materiałowa w WSJP PAN - kolokacje i cytaty, [w:] P. Żmigrodzki, M. Bańko, B. Batko-Tokarz, J. Bobrowski, A. Czelakowska, M. Grochowski, R. Przybylska, J. Waniakowa, K. Węgrzynek (red.), Wielki słownik języka polskiego PAN. Geneza, koncepcja, zasady opracowania, Kraków, s. 115-126.

SкORUPKA S., 1967-1968, Słownik frazeologiczny języka polskiego, t. I-II, Warszawa.

USJP: S. Dubisz (red.), Uniwersalny słownik jezzyka polskiego, t. I-IV, Warszawa 2003.

Wielki słownik języka polskiego PAN. Geneza, koncepcja, zasady opracowania, praca zbiorowa, red. P. Żmigrodzki, M. Bańko, B. Batko-Tokarz, J. Bobrowski, A. Czelakowska, M. Grochowski, R. Przybylska, J. Waniakowa, K. Węgrzynek, Kraków 2018.

WSJP PAN: P. Żmigrodzki (red.), Wielki słownik języka polskiego PAN, [on-line:] www. wsjp.pl.

\section{Collocations and Semantic Analysis of Words \\ Summary}

The author presents the application of an electronic text corpus, particularly of NKJP for Polish, to the analysis of syntagmatic expressions, more commonly known as collocations. By querying a corpus, it is possible to obtain reliable data on the frequency of collocations, and to extract cognitively significant expressions. 